\title{
Influence of different mulch material on different growth and yield attributes of turmeric (Curcuma longa L.) Cv. Rajendra Sonia
}

\author{
Kumari Vibha Rani*, U.N.Umesh, Suraj Prakash ${ }^{1}$, Jyoti Sinha and Brajendu Kumar \\ Krishi Vigyan Kendra, Harnaut, Nalanda, B.A.U. Sabour, Bhagalpur (Bihar) India \\ (Email : kumarivibhaa1@gmail.com)
}

\begin{abstract}
An on farm trial was conduct in different villages of nalanda district during financial year 2018-19 and 2019-20 respectively by krishi vigyan kendra Harnaut Nalanda The research trials was conducted for continuous two years and we got the followings results as the maximum plant height $116.37 \mathrm{~cm}$, the maximum number of leaves per planet 9.30 , number of rhizome per plant is 19.50 , maximum rhizome yield $313.72 \mathrm{Q} /$ Hectare and dry weight of rhizome $63.03 \mathrm{q} / \mathrm{ha}$ was recorded in call of bicolor black/ silver plastic mulch applications compared to other treatment during financial year 2018-19 and during 2019-20 the maximum plant height $118.29 \mathrm{~cm}$, no of leaves per plants 9.50 ,number of rhizome per plant is 21.33 , maximum rhizome yield 316.46 $\mathrm{Q} /$ Hectare and dry weight of rhizome $66.76 \mathrm{q} / \mathrm{ha}$ were recorded in case of bicolor black/silver plastic mulch application is compared to other treatment.
\end{abstract}

Key Words : Turmeric, Mulch, Black/silver (Bicolor) plastic, Paddy straw, Rhizomes, Curcumin

View Point Article : Rani, Kumari Vibha, Umesh, U.N., Prakash, Suraj, Sinha, Jyoti and Kumar, Brajendu (2021). Influence of different mulch material on different growth and yield attributes of turmeric (Curcuma longa L.) Cv. Rajendra Sonia. Internat. J. agric. Sci., 17 (AAEBSSD) : 92-97, DOI:10.15740/HAS/IJAS/17-AAEBSSD/92-97. Copyright@2021: Hind Agri-Horticultural Society.

Article History : Received : 11.07.2021; Revised : 14.07.2021; Accepted : 18.07.2021

\section{INTRODUCTION}

Turmeric is one important spice crop grown in India. It has a botanical name curcuma longa L. and belongs to family Zingiberaceae. It is rhizomatous herbaceous perennial plant. It is also called as golden spice and Indian saffron due to its brilliant yellow color. The area under turmeric cultivation in India during different financial year in was 186 thousand hectare with production of 943 thousand metric tons during 2015-16,222 thousands hectare with production of 1056 thousands metric tons during financial year 2016-17 and 238 thousand hectare with production of 1133 thousand metric tonsduring financial year 2017-18 (source :horticultural statistics at a glance 2018)

The contribution of Bihar state was three thousand metric tons hectare with production of three thousand metric tons during FY 2015-16 2.44 thousand hectare with production of 2.63 thousand metric tons during FY 2016-17 and 2.72 thousand hectare with production of 2.83 thousand metric tons during FY 2017-18 (source

* Author for correspondence :

${ }^{1}$ Bhola Paswan Shastri Agricultural College (B.A.U.), Purnea (Bihar) India 
:horticulture statistics division department of agriculture cooperation and farmers welfare.

The productivity in the same financial year was 1 metricton per hectare during F-Y2015-16, 1.08 metric ton per hectare during 2016-17 and 1.04 metric ton per hectare during FY 2017-18.From overall production India consumes about 80 per cent of total. Onquality aspect the turmeric has higher curcumin content is better as compared to other. Curcumin is an important bioactive compound present in it and have great medicinal value. Turmeric of India is considered as best in the world The city Erode of Tamil Nadu is called as yellow city or turmeric city due to largest production and the most important trading centre in the world. At second place the city Sangli of Maharastra follows for production and trading site.

Before use of the turmeric the rhizomes must be boiled or processed to remove the grow order uniform coloring of product and gelatinization of starch. For getting quality produce rhizomes are placed in 0.05 to $0.1 \%$ solution of sodium bicarbonate in large iron vats and then boiled for 40 to 45 minutes

Then rhizomes are removed immediately from the water and sum dried to prevent overcooking. The moisture content in dried rhizomes varies between 8 to $10 \%$ on wet basis. For general identification the metallic sound comes from rhizomes by finger tapping is perfect for storage and final product. For removing the rough surface the rhizomes are polished. Turmeric has diverse uses such as in foodstuff, cosmetic, medicine, flavor color ingagent in different food stuffs butter cheese etc. It is also widely used in food processing industries in dairy products, yellow cakes, baked products, ice-cream biscuits etc.

The consumption of turmeric in Asian countries is in the range of $200-1000 \mathrm{mg} / \mathrm{day}$ as per report of Thimmayamma, Rau and Radhaiah 1983; Polasa etal .1991 or 160 to $440 \mathrm{gm}$ per person per year as per report of Krishnawamy, 1996. Consumption of turmeric is higher in rural areas $600 \mathrm{mg} /$ day/person than urban area $200 \mathrm{mg} /$ day as per findings of Thimmayamma, Rau,and Radhaiah 1983. As per report of Dixit, Jain and Joshi, 1988 turmeric is used as an herbal medicine for treatment of wound healing, liver ailments, urinary tract infections, chickenpox, smallpox, skincancer,conjunctivitis, rheumatoid arthritis. It is also used in treatment of abdominal pain, menstrual difficulties, jaundice and digestive disorder as per Bundy et al., 2004 and anti- inflammatory, antimicrobial, carminative actions as per Mills and Bone, 2000.

In India it is used in various ayurvedic applications such as to purify blood and remedy of skin diseases. In rituals turmeric powder is used in various ways such as in marriage ceremonies, worship etc. In recent trend it is widely used in different sunscreens and face creams based on turmeric as per findings of Araujo and Leon, 2001. It is well documented as ayurvedic medicine for treatment of liver disorders, respiratory disorder, rheumatism, runny nose and diabetic wound as per report Araujo and Leon, 2001. It is used in treatment of swelling and sprains since ancient times.

Turmeric has strong in antimicrobial properties as per findings of Paramasivam, Thangaradjou and Kannan, 2007 the 5\% concentration of garlic and turmeric extract inhibited the growth of Vibrio parahaemolyticus, Bacillus cereus, Pseudomonas aeruginosa and Proteus mirabilis. The curcumin of turmeric have very strong ant carcinogenic property it inhibit the cell proliferation of carcinogenic cells so, turmeric have multifarious use not only for humans and also for animals .In commercial cultivation of turmeric the weed, insect pest and disease infestation is a major problem. To overcome these types of problems I had conducted on farm trial on commercial cultivation of turmeric with the use of different types of mulch materials.

\section{Metrological observations:}

The climate of Nalanda district is hot during summer and cool in winter. It experiences medium to heavy rainfall. The annual average rainfall is near about 120 $\mathrm{mm}$. Rainy season generally begins from mid June Most of the precipitation generally occurs between mid June to mid September. Themonthly rainfall data for financial year 2018 to 2020 is enclosed in it. It reveled that maximum rainfall $299.32 \mathrm{~cm}$ occur during August in year $2018,409.32 \mathrm{~cm}$ during July in year 2019 and $287.36 \mathrm{~cm}$ during September in year 2020. The distribution of rainfall during this finanacial year is presented in Table 1.

\section{Soil properties of the district and farmers field:}

Nalanda district have diverse range of soils in different locality mainly are alluvial deposit from southern Ganga plain. The major soil types are clay loam, fine loam, loam and coarse loam. The range of various nutrients in different blocks of Nalanda district is varies from $\mathrm{pH}$ value lies in range of 6.54 to 8.13 , organic carbon 
Influence of different mulch material on different growth \& yield attributes of turmeric

\begin{tabular}{|c|c|c|c|c|c|}
\hline Sr.No. & & Normal rainfall $(\mathrm{mm})$ & 2018 & 2019 & 2020 \\
\hline 1. & January & 14.5 & 0 & 8.98 & 10.72 \\
\hline 2. & February & 13.6 & 1.96 & 16.65 & 17.46 \\
\hline 3. & March & 8.7 & 0 & 3.09 & 56.30 \\
\hline 4. & April & 8.7 & 12.99 & 3.66 & 31.39 \\
\hline 5. & May & 22.6 & 14.29 & 30.03 & 62.16 \\
\hline 6. & June & 127.7 & 73.50 & 38.54 & 205.37 \\
\hline 7. & July & 252.8 & 299.32 & 232.54 & 215.11 \\
\hline 8. & August & 282.7 & 173.36 & 149.92 & 189.03 \\
\hline 9. & September & 188.6 & 102.2 & 409.32 & 287.36 \\
\hline 10. & October & 47.4 & 14.6 & 11.2 & 24.32 \\
\hline 11. & November & 8 & 0 & 0 & 0.91 \\
\hline 12. & December & 2.6 & 4.98 & 27.37 & 0 \\
\hline Total & & 977.9 & 697.2 & 931.3 & 1100 \\
\hline
\end{tabular}

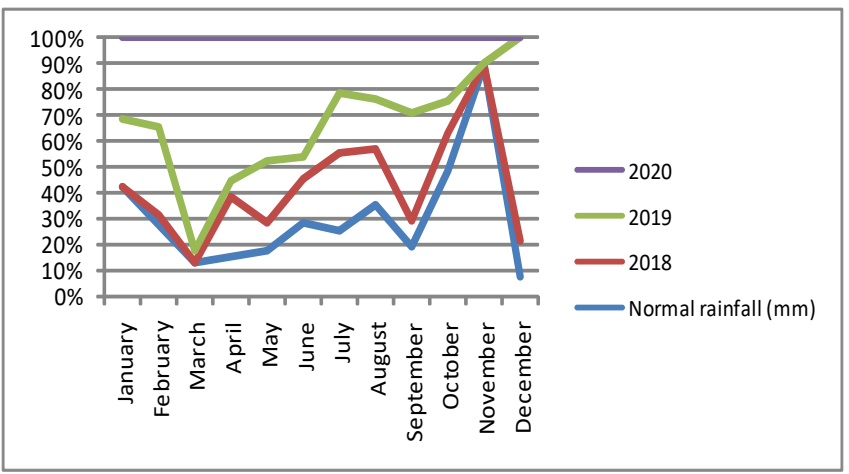

from 0.35 to 0.65 , EC is from 0.047 to $7.5 \mathrm{Ds} / \mathrm{m}$, available Nitrogen from 190.5 to $275.5 \mathrm{~kg} /$ ha, available phosphorus from 21.5 to $55 \mathrm{~kg} / \mathrm{ha}$ and available potash from 148.5 to $236.5 \mathrm{~kg} / \mathrm{ha}$ as per data mentioned in Table 2 .

The average value post harvest soil properties of different trial plots is maximum $\mathrm{pH}$ value is 7.24 , organic carbon 0.634 , nitrogen $323 \mathrm{~kg}$ per ha, $\mathrm{P}_{2} \mathrm{O}_{5} 34.6 \mathrm{~kg}$ per ha and $\mathrm{K}_{2} \mathrm{O} 171 \mathrm{~kg}$ per ha is reported in application of paddy straw mulch as compared to other treatments. The EC value is minimum 0.034 in treatment of paddy

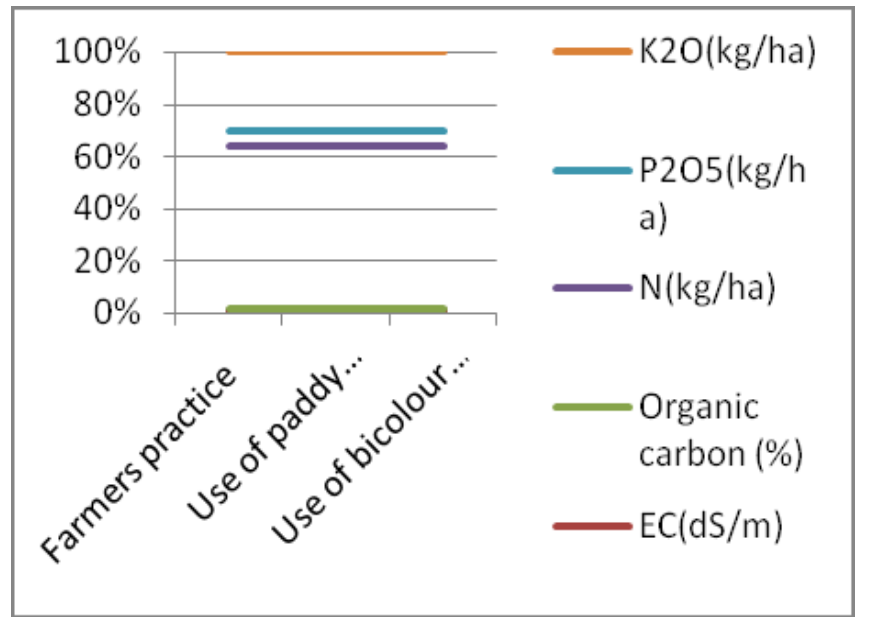

straw mulch as compared to other treatments.

\section{Material AND Methods}

This on farm trial was conducted during two consecutive financial years 2018-19 and 2019-2020 in different villages of Nalanda district. The total area of

\begin{tabular}{|c|c|c|c|c|c|c|}
\hline \multirow{2}{*}{ Treatments } & \multirow{2}{*}{$\mathrm{pH}$} & \multirow{2}{*}{$\mathrm{EC}(\mathrm{dS} / \mathrm{m})$} & \multirow{2}{*}{$\begin{array}{c}\text { Organic } \\
\text { carbon }(\%)\end{array}$} & \multicolumn{3}{|c|}{ Available nutrients (kg/ha) } \\
\hline & & & & $\mathrm{N}$ & $\mathrm{P}_{2} \mathrm{O}_{5}$ & $\mathrm{~K}_{2} \mathrm{O}$ \\
\hline Farmers practice & 6.80 & 0.748 & 0.647 & 372 & 36 & 182 \\
\hline Use of paddy straw as mulch material ( $6 \mathrm{~cm}$ thickness) & 6.78 & 0.742 & 0.654 & 380 & 33.8 & 186 \\
\hline $\begin{array}{l}\text { Use of bicolour (Silver/black) plastic as mulch ( } 25 \\
\text { micron thickness) }\end{array}$ & 6.81 & 0.745 & 0.649 & 376 & 35 & 181 \\
\hline S.Em. + & .02 & 0.002 & 0.002 & 2.21 & 0.76 & 2.32 \\
\hline C.D.@ $5 \%$ & NS & NS & 0.006 & 6.62 & NS & 6.95 \\
\hline
\end{tabular}


Kumari Vibha Rani, U.N.Umesh, Suraj Prakash, Jyoti Sinha and Brajendu Kumar

Nalanda district is 2355 square kilometer with cultivable land 181130 ha. So many rivers like Phalgu, Jirayan, Kumbhori and Mohane are flow through this district. Major part of land in this district has fertile land due to Indo Gangetic plane. This district is rich in biodiversity with wide range of natural resources in the hills and hillocks of Rajgir. This trial was conducted for increasing the yield and improving the quality by optimum use of natural resources. This trial was conducted with three treatments and eight replications on farmer's field. The first treatment was farmers practice manual hand weeding second treatment was mulch of paddy straw with $6 \mathrm{~cm}$ thickness and third was black plastic mulch with 30 micron thickness.

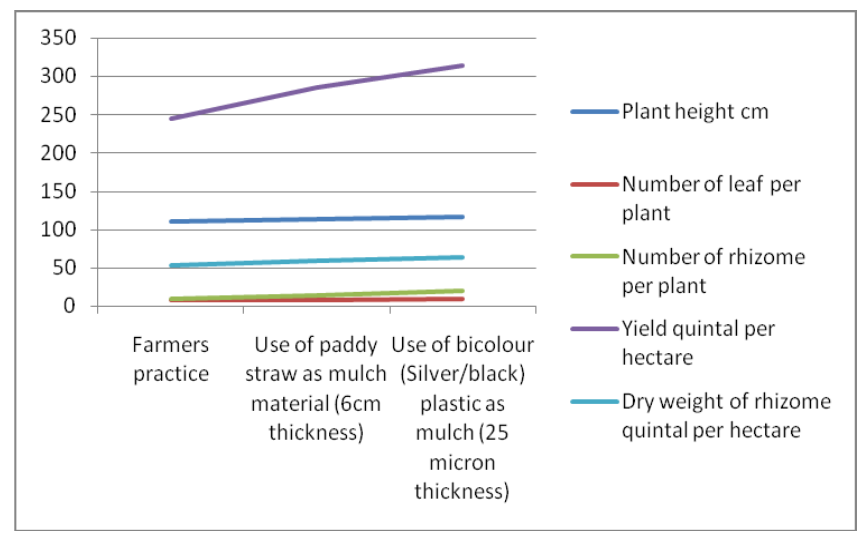

\section{Results AND Discussion}

Mulching is an important operation carried to conserve moisture and enhance proper germination of rhizome. As per findings of Onwueme (1978) mulching is most useful in moisture conservation and helps in sprouting of seeds. Awal et al. (1978) and Jha et al.(1986) reported that mulching is much beneficial in case of root and tuber crop after sowing. It also checks weed growth and improves the fertility status of soil after decomposition of weeds. As per findings of Randhawa (1969) and Mohanty (1977) mulching prevents soil erosion and nutrient loss due to heavy rain. Mulching enhances the yield as per findings of Aclan (1976) and Mohanty

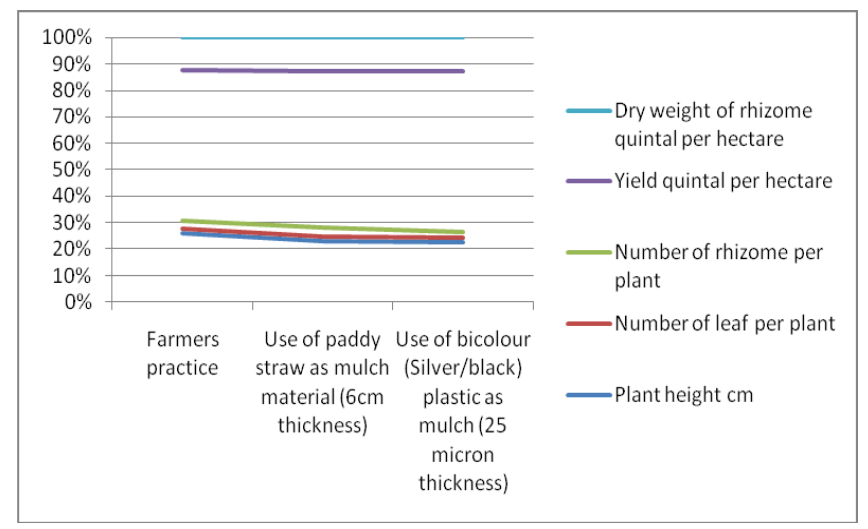

\begin{tabular}{|c|c|c|c|c|c|}
\hline Treatments & $\begin{array}{l}\text { Plant height } \\
\mathrm{cm}\end{array}$ & $\begin{array}{l}\text { Number of leaf } \\
\text { per plant }\end{array}$ & $\begin{array}{l}\text { Number of } \\
\text { rhizome per } \\
\text { plant }\end{array}$ & $\begin{array}{l}\text { Yield quintal } \\
\text { per hectare }\end{array}$ & $\begin{array}{l}\text { Dry weight of } \\
\text { rhizome quintal per } \\
\text { hectare }\end{array}$ \\
\hline Farmers practice & 111.07 & 7.80 & 9.70 & 244.18 & 52.35 \\
\hline Use of paddy straw as mulch material ( $6 \mathrm{~cm}$ thickness $)$ & 113.71 & 8.50 & 13.50 & 285.65 & 58.42 \\
\hline $\begin{array}{l}\text { Use of bicolour (Silver/black) plastic as mulch ( } 25 \\
\text { micron thickness) }\end{array}$ & 116.37 & 9.30 & 19.50 & 313.72 & 63.03 \\
\hline S.Em.+ & 0.307 & 0.17 & 0.37 & 0.79 & 0.28 \\
\hline C.D.@5\% & 0.646 & 0.36 & 0.77 & 1.67 & 0.598 \\
\hline
\end{tabular}

\begin{tabular}{lcccc}
\hline Table 4: Effect of mulching on different quantitative and qualitative parameters in Turmeric Cv. Rajendra Sonia. FY-2019-2020 with graphical \\
repres entation
\end{tabular}


Influence of different mulch material on different growth \& yield attributes of turmeric

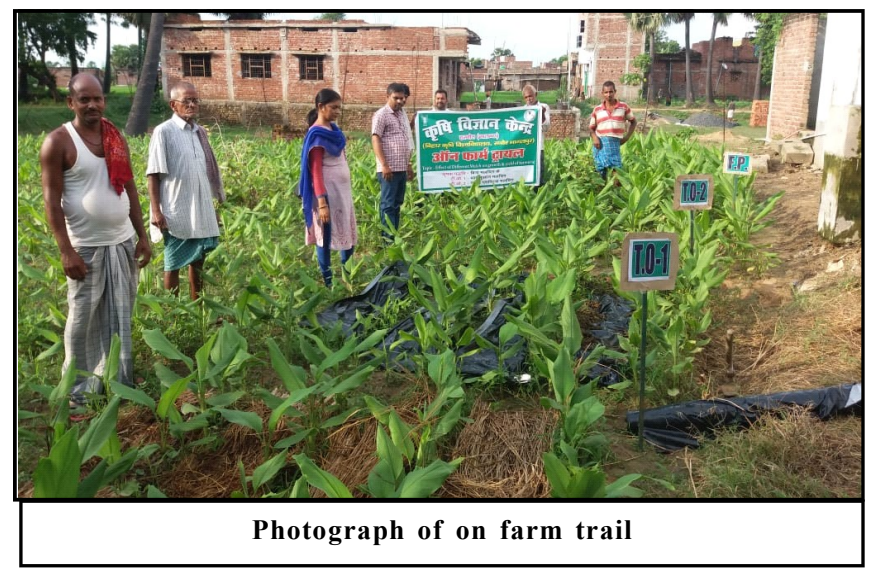

and Sharma (1978). We studied the various parameters such as plant height, number of leaves per plant, number of rhizomes per plant, yield quintal per hectare and dry weight of rhizome quintal per hectare for getting the effect of mulching on these parameters in turmeric.

The maximum plant height $116.37 \mathrm{~cm}$ and 118.29 $\mathrm{cm}$, average number of leaves per plant9.30 and9.50, average number of rhizomes per plant 19.50 and 21.33 , yield 313.72 and 316.46 quintal per hectare and dry weight of rhizome 63.03 and 66.76 quintal per hectare were recorded in case of bicolor (black/silver) plastic mulch as compared to other treatments. The similar findings were also reported by Kumar et al. (2018) the maximum plant height $(68.697 \mathrm{~cm})$, other parameters is recoded in plastic mulch as compared to other treatment. This is due to affect of plastic mulch on suppression of weed growth, check in the soil erosion, enhances the nutrient uptake and water availability to plants. It is due to reduction of weed crop competition in mulched plot as compared to unmulched plot. As per findings of Gill et al. (1999) and Junior et al. (2005) and Vanlalhluna et al. (2010) mulching application helps in early sprouting of turmeric due to moisture retention. The maximum plant height, number of leaves, number of rhizomes, weight of rhizomes and yield were also recorded by Zaman et al. (2002). Similar results were also found by Ashworthy and Harrisson (1983). The similar findings were also reported by Kalyankar et al. (2011) and Reddy et al. (2017). As per findings of Nick et al. (1969), Mannan and Rashid.(1983) the yield of mulched plot is higher than non-mulched plot.

\section{Conclusion:}

The application of Bicolor plastic mulch is best treatment as compared to other treatments and control plot. By mulch application farmers can get higher produce yield, better quality, and lesser weed infestation and lower the incidence of pest and diseases. It reduces the cost of cultivation and increase the profit of farmers and improve the $\mathrm{B}: \mathrm{C}$ ratio also.

\section{REFERENCES}

Araujo C.C. and Leon L.L. ( 2001). Biological activities of Curcuma longa L. Mem. Inst. Oswaldo. Cruz., 96:723-8.

Ashworth, S. and Harrisson (1983). Evaluation of mulches for use in the home garden. Hort.Sci.,18:180-182.

Awal, M.A., Hossain, M.M. and Rashid, M.M.(1978). The effect of method of seed bed prepration,mulching and intertillage on the growth and yield of mukhi kachu (Colocasia esculenta var globulifera) Bangladesh Hort., 6 (1-2) : 9-13.

Bundy, R.,Walker,A.F., Middleton, R.W. and Booth, J. (2004). Turmeric extract may improve irritable bowel syndrome symptomology in otherwise healthy adults: A pilot study.J Altern Complement Med.,10:1015-1018.

Dixit, V.P, Jain, P, Joshi, S.C. (1988). Hypolipidaemic effects of curcuma longa L. and Nardostachys jatamansi, DC in tritoninduced hyperlipidaemic rats. Indian J. Physiol. Pharmacol., 32 : 299-304.

Gill, B.S, Randhawa, R.S, Randhawa, G.S. and Singh, J. (1999). Response of turmeric (Curcuma longa L.) to nitrogen in relation to application of farmyard manure and straw mulch. $J$. Spices aromatic xrop, $8: 211-214$.

Jha, R.C., Maurya, K.R. and Pandy, R.D. (1986). Influence of mulching on the yield of ginger in Bihar. Indian Cocoa Arecanut Spices J., 9 (4) : 87-90.

Junior, M.A., Borella, J.C., Franca, S.C. and Masca, M.G.C.C. (2005). Effects of type of rhizome used to proliferation and mulching on growth and productivity of turmeric (Curcuma longa L.) Rev. Bras. Plantas. Med., 8 : 30-34.

Krishnaswamy, K. (1996). Indian functional foods: Role in prevention of cancer. Nutr Rev., 54 : S127-31.

Kumar, M., Dubey, S., Dwivedi, P.K.,Yadav,A.K. and Kumar, M. (2018). Influence of different mulch materials on vegetative growth and yield of ginger (Zingiber officinale Rosc.) under drip irrigation system.

Mannan, M.A. and Rashid, M.M. (1983). Effect of spacing and mulching on the yield and profitability of pancha mukhi kachu. Bangladesh J.Agril.Res.,8 (2) : 70-73.

Mills, S. and Bone, K. (2000). Principles and practice of phytotherapy. Toronto, ON: Churchill Livingstone;.

Nick, J., Moody, J.E. and Lillard, J.H. (1969). Effect of number 
of tillage and mulch on soil water and plant growth. Agron. J., 61 (15) : 719-721.

Onwueme, I.C. (1978). The tropical tuber crops. John Wiley and Sons, Chichester, pp.199-227.

Paramasivam S., Thangaradjou and Kannan, L. (2007). Effect of natural preservatives on the growth of histamine producing bacteria. J. Environ. Biol., 28 : 271-274.

Polasa, K., Sesikaran, B., Krishna, T.P. and Krishnaswamy, K. (1991). Turmeric (Curcuma longa)- induced reduction in urinary mutagens. Food Chem. Toxicol.,29 : 699-706.
Thimmayamma, B.V.S., Rau, P. and Radhaiah, G. (1983). Use of spices and condiments in the dietaries of urban and rural families. J. Indian Nutri. Diet.

Vanlalhluna P.C, Sahoo U.K. and Lalremruati J.H. (2010). Relative efficacy of different mulch types on soil moisture conservation and performance of rain fed turmeric in an agro forestry system of Mizoram. Range Manag Agrofor., 31(1) : 31-35.

Zaman M.M., Mausam M.H.,Ahmed N.U., Salam M.A. and Rahman, M.H. (2002). Effect of tillage and mulch on the growth and yield of ginger in the hilly area, 2 (2) : 121-123.

\section{$17_{\text {Ycar }}^{\text {th }}$}

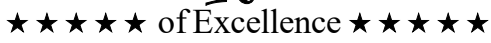

